\title{
The Identity of Higher Learning Student's in Malaysia: A Preliminary Study
}

\section{Fariza Md Sham}

Institute of Islam Hadhari, Faculti of Islamic Studies, The National University of Malaysia; farisham@ukm.edu.my

Jawiah Dakir

Institute of Islam Hadhari, The National University of Malaysia; jawiah@ukm.edu.my

Mohd. Yusof Hj. Othman

Institute of Islam Hadhari, The National University of Malaysia; myho@ukm.edu.my

Noralina Omar

Department of Social Administration \& Justice, Faculty of Arts \& Social Sciences

University of Malaya; nora2374@yahoo.com

\section{Siti Maheran Ismail@lbrahim}

Institute of Islam Hadhari, The National University of Malaysia; maheran@ukm.edu.my

Mujahid Abu Bakar

Institute of Islam Hadhari, The National University of Malaysia; mujahid@ukm.edu.my

\author{
Doi:10.5901/mjss.2015.v6n6s1p430
}

Abstract

This study aims to examine the level of identity of students in selected public universities in the Klang Valley, Malaysia. Components of identity assessed in this study are the language, customs, culture, religion, patriotism, integrity, idealism and institutional contributions. All these components are examined in their manifestations through the respondents' knowledge, behavior, emotions, values and beliefs. The methodology used is survey with quantitative approach. Questionnaires answered by respondents form the research data collection tool. A total of 800 male (46\%) and female (54\%) students from four selected universities with multi-year and multi-field of study comprising of three main ethnic groups (66.8\% Malay, $22.9 \%$ Chinese \& $10.3 \%$ Indian) were selected as respondents. The study found that 54.6 percent of respondents have a high level of selfidentity. In addition, age, gender, ethnicities, place of origin, field of study and institutions where respondents learn play a role in determining the level of identity. All components of identity also showed significant differences based on ethnicity, field of study and learning institution. In conclusion, the level of identity for this sample, even though not alarming as yet, should give a strong signal to all parties that there are threats to national identity. Therefore, continuous efforts should be made to strengthen and reinforce national identity.

Keywords: identity, moral character, young generation, higher learning students, learning institution.

\section{Introduction}

Lack of sound identity among the young generation is often a cause of concern to the adult community. On the one hand the young generation is commonly known for their propensity such as for wanting to try new things and being easily influenced to imitate. On the other hand, the young generation is expected to lead the nation in the future. The identity is often associated with the character and dignity of an individual, society or nation. The formation of a national identity is integral to and becomes a major agenda of a nation-state for the purpose of establishing a genuine and noble identity as the core and symbol of national greatness and excellence (Ismail Bakar 2010). Its formation is a process to strengthen the society's confidence in their belief system so that when each member of society adheres to religious teachings, he will 
not do something which is not good (Ismail Bakar 2010). Religion is thus an important part of national identity (Dingley 2009). Religion will form and transmit ideas of truth, both moral and cognitive (Dingley 2009).

According to Ismail Ibrahim (2010b), the identity for a Malaysian is quite a complex matter due to the nation's acceptance of diversity of race, religion, culture and language. Moreover, throughout her history, Malaysia has never adopted a policy of assimilation which melts diverse ethnicities with different languages and cultures into the value of one national identity but has always, instead, practised a policy of peaceful co-existence of diverse communities and races (Ismail Ibrahim 2010b). However, Ismail opines that as the Malaysian Constitution encompasses the legal, social, religious, language systems and so on, an affirmation as a Malaysian citizen is the recognition of the identity which is committed to the climate and landscape of the nation as a whole.

The Malaysian Constitution in clearly stating details of religious affairs and its practice, the national language policy, policies of affirmative privileges of Malays and indigenous people, and matters which protect the interests of other communities and other religions, presents important features for the establishment of a Malaysian nation-state (Ismail Ibrahim 2010a). Thus, Ismail Ibrahim (2010a) argues that citizens should duly recognise that their identity and moral character are deeply based on the Malaysian Constitution, and national policies framed within the perimeters of the said constitution.

The objective of the research is to study the level of identity among students in tertiary institutions in Malaysia. The issue to be addressed in this study is the level of identity among students of tertiary institutions in this nation. This study will also answer other issues related to identity, that is, the differences in levels of identity based on age, gender, place of origin, ethnicity and field of study.

\section{The Concept of the Identity}

According to the Dictionary of Dewan (2007) the identity is the traits or characteristics that occurs in a person. These features are often the basis for people distinguished themselves from others, identify himself or be identified by others. From the perspectives of demographics, identity based on factors such as gender, age, religion, family, language and ethnicity (Aboriginal Peoples Act 1954). From a perspective Islamic psychology, identity refers to physical attributes and personality, including personality, character and behaviour of an individual (Fariza 2013). Personality, according to alGhazali (2000), the identity covering both external and spiritual behavior such as emotions, motivation and attitude, that called akhlak (morals). Therefore, it is concluded that the indicators in the determination of identity can be seen from several aspects. Including cultural aspects (Samsudin A. Rahim 2001), customs, ahklak and behaviour, values and norms of society, religious, economic and social activities.

According to Mendelsohn (2002), identity may refer to two things, that is, characteristics and qualities which are shared within a community and how individuals define themselves. Chi-Huang (2005) considers identity as socially constructed categories of membership whereas self identity involves the identification with, and choice of, sovereignty, territorial jurisdiction, and citizenship. In related to that, self-identity is a feature or characteristic which is unique and special in terms of custom, culture, religion, etc which form the core in the formation of the personal character and symbol of an individual, society or a nation (Oxford Dictionary 4th Edition 2005). It may also refer to an individual's own real identity or character, whether possessed from birth or acquired, inclusive of values adhered to (Wan Muhamad 2010).

Whereas, national identity which defined by De La Torre (in Matera et al. 2005) is a socio-psychological space of belonging, as identification with some significant traits, and as a consciousness, more or less elaborated, of sharing a space of life. National identity according to Fox means any characteristic features shared within a society and distiguishes them from other groups (Desai 2006). However, in this paper, we used identity to refer elements of language, customs, culture, religion, patriotism, integrity, idealism and institutional contributions in forming the personal character of an individual.

A review of earlier studies on national identity finds that it is often associated with race or nation. This is so because it is closely related to the reference model for developing a race, culture or state governance. For example, ChiHuang (2005) studied the identity of the Taiwanese race and Chinese in Taiwan, Kurth (2007) studied the identity in America and Europe, Tartakovsky (2010) studied identity in Russia and Ukraine, and Burbank (2010) studied identity in Germany. In Malaysia, there have been few studies on identity. Among them is Tan (2000) who studied the relationship between national and ethnic identity, Desai (2006) who studied national identity in a multi-cultural society and Lee (2009) who studied identity among ethnic Chinese.

In the Malaysian context, national identity needs to be linked to ethnicity in view of national identity being frequently described differently by different ethnic groups in a country (Tan 2000). According to Desai (2006), national identity in the Malaysian context is closely linked to ethnic composition as Malaysia is a multi-ethnic state. 
Religion is an important component in national identity (Dingley 2005). Religion is also central to identity formation in Kurth's (2007) study of the society in America and Europe. In his writing, Kurth (2007) has identified the importance of religion's role in the formation of identity for the society in both places. Theriault and Peter (2005) and Zambeta (2000) also affirm the role of religion as an important element in shaping the identity of the society in European nations. In fact, religion played a critical role in the past in the formation of Greek national identity (Zambeta 2000).

In the history of Islam, it is also proven that the first process done by the Prophet (pbuh) towards the early generation of Muslims was to form an identity which could withstand any form of mental and physical pressures along with the capacity to display the qualities of kindness, honesty and sincerity based onthe eternal spirit of the religion embraced (Ismail Bakar 2010). Miedema (2009) is also of the opinion that religious identity is part of individual identity. Legally, Islam is central to the formation of a national identity based on the provisions of the Federal Constitution (Zainul Rijal 2010).

The interpretation of Islam in Malaysia generally affirms the role of a healthy arts and cultural life, that is, one which can develop creativity to foster the value of healthy human cultural arts not inconsistent with the principles and spiritual values of Islam (Ismail Ibrahim 2010b). Society should not abolish all institutions of cultural arts which are not inconsistent with the core principles of Islam, but should instead see cultural arts as an institution which canenliven Islamic symbols in society (Ismail Ibrahim 2010b). This is where religion and culture relate in the formation of identity. Culture is fundamental to a society's identity which consists of many components such as tradition, customs, belief system, values, arts, knowledge and other norms practised by a group of individuals in a society (Ennaji 2005).

Culture and language are closely linked (Ennaji 2005). Language is important in developing identity and plays a symbolic role in depicting cultural elements (Ennaji 2005). Language is the medium in the process of imparting knowledge (Nor Hashimah et al. 2010). In fact, embedment of the national ideology, Rukunegara, can be done through language. Such efforts to embed the principles of Rukunegara through language to improve the self-identity of the young generation, for example, is being done by making selected novels as secondary school text (Misran 2006).

Language plays an important role in determining identity and national identity. In Catalonia (Spain), for example, there exists a complex interrelationship between language, identity and nationhood (Marshall 2009). There occurred in Catalonia large scale migrations which resulted in rivalry to promote and preserve the respective ethnic languages (Marshall 2009). This shows that language is important as a symbol of national identity for a state.

Realizing the importance of language in developing identity in multicultural Malaysia, studies were done to determine how literature plays a role in developing identity among children (Desai 2006). Besides this, the government has set up a Malay Language Acculturation Division under the administration ofthe Ministry of Information, Communication and Culture in efforts to ensure that the Malay language is effectively used as a national language by the pluralistic society in this state (Utusan Malaysia 29 October 2010).

Why is it necessary to study issues related to the identity? The following are some of the findings from earlier studies related to such issues.

The Special Unit of Utusan Malaysia once conducted a study of 200 respondents of which $89.5 \%$ consist of young adults within the age range of 15 to 30, regarding history and general knowledge of Malaysia (Utusan Malaysia 28 Oktober 2010). The said study concluded that today's adolescents lack interest in history; do not care about nationhood and take patriotism lighty. Thus, the question arises as to the effectiveness of the public educational system in inculcating identity among its population. Collet (2007) however, is of the opinion that formal public school education is the best place to learn and practise national identity. Ramlah (2005) in her study found that only $70 \%$ of respondents consisting of higher learning students in Malaysia are able to properly memorise the Rukunegara. In addition, knowledge of Rukunegara is better among female respondents and those from urban areas. Besides that, the said study found that the level of willingness to sacrifice for the nation among respondents is still low (Ramlah 2005). In addition, students majoring in literature/arts are more exposed to Rukunegara in their course studies (Ramlah 2005). What is happening to the young generation who will be the future leaders?

Burbank (2010) in his study of 795 respondents from 2 different age cohorts found that the older generation in Germany have a higher level of patriotism, national identity and ethnocentrism as compared to the youger generation. If so, is this current situation in Malaysia?

As regards ethnic groups, Tartakovsky (2010) in his study on adolescents in Russia and Ukraine found that adolescents from the majority group have a more positive attitude towards the nation and stronger identity. So what is the situation in the Malaysian context?

Overall, identity related issues explained above give an impression of how necessary it is to study current levels of the identity among the young generation. Thus, based on earlier studies and commentaries of experts, this study will examine some issues related to the identity from a Malaysian perspective. 
Therefore, the components of the identity assessed in this study are the language, customs, culture, religion, patriotism, integrity, idealism and institutional contributions. The level of identity in students of tertiary institutes has to be first determined as this group will be the nation's future leaders, whereby a high level of this identity is required to sustain the nation's sovereignty and prosperity. The findings of this study are expected to give the current picture of the level of the identity among the nation's young generation as well as provide input to authorities responsible for enhancing national identity among Malaysians. The findings of this study may also be the source of information in developing effective programs to build national identity, enhance, if necessary, the national curriculum, and improve existing policies or formulate new policies in keeping with the times

\section{Materials and Methods}

This is a descriptive study. The research design uses survey methodologies with quantitative approach. Questionnaires answered by respondents are the data collection tool. The sampling method used is stratified random sampling.The research sample consists of tertiary institution students. This group is identified for their future role as frontline leaders. Only three ethnic groups are chosen, that is, Malay, Chinese and Indian. This is based on the ethnic percentage of the year 2010 (according topopulation forecast based on Population Census 2000) which show that Malays, Chinese and Indians are the major ethnic groups in comparison to other ethnic groups (Department of Statisitc Malaysia 2010). Public universities are selected as study locations as all students are required to attend nationhood and civilizational courses which can improve the identity.Four universities in the Klang Valley, Malaysia are selected, that is, Universiti Kebangsaan Malaysia (UKM), Universiti Putra Malaysia (UPM), Universiti Teknologi Malaysia (UTM) and Universiti Malaya (UM).

The measurement of the identity used in this study contains 59 items related to language, custom, culture, religion, patriotism, integrity and idealism which best reflect individuality. Scoring for items 7 to 59 is by using Likert scale of answer options ranging from $5=$ strongly agree, to $1=$ strongly disagree. Respondents with higher scores indicate a better identity as compared to respondents with lower scores. The value of the alpha coefficient reliability measurement instrument test is 0.96 .

\section{Results and Discussion}

The total of research respondents is 800 persons. Most of them are aged between 19 and 23. The average age is 21.4 years $(\mathrm{Sp} .=1.84)$. The majority of respondents are female.As many as $66.9 \%$ of respondents are Malay, $22.9 \%$ are Chinese and $10.3 \%$ Indian. Majority of them are from the urban areas. Most of them study in the literature/arts stream in their respective institutes of learning, followed by science and technical streams. And most of them had gone through national or public secondary education (Table 1).

Table 1: Background of Respondents

\begin{tabular}{lcc}
\hline Characteristics & $\mathrm{n}$ & $\%$ \\
\hline Age: $(M=21.4, \mathrm{Sp} .=1.84)$ & 728 & 91 \\
18-23 years & 72 & 9 \\
23 years and above & & \\
Gender: & 368 & 46 \\
Male & 432 & 54 \\
Female & & \\
Ethnicity: & 535 & 66.8 \\
Malay & 183 & 22.9 \\
Chinese & 82 & 10.3 \\
Indian &
\end{tabular}

Place of Origin: 
Urban

438

362

45.3

Rural

Field of Study :

Science

Arts \& Social Science

341

42.6

Technical

142

17.8

Year of Study :

Year 1

266

33.3

Year 2

255

31.9

Year 3

279

Notes $n=$ no. of subjects, $\%=$ percentage

\section{Measurement of the Identity}

Findings of this study show that a large number (54.6\%) of research respondents are young adults with a high degree of identity. This is in line with the findings of Tan's (2010) research.He found that the level of practice of Rukunegara which is part of the symbol of a strong the identityis high among trainee teachers who are also the young generation. It is not, however, denied that Ab Rahman and Amidin (n.d.) found the practice of noble values which are part of the element of integrity in the identity at an average level among secondary school students. Nevetheless, the high level of identity of the majority of respondents inthis study is probably due to the role of educational institutions in building identity.

The findings also show that female respondents have a better identity as compared to male respondents. Score analysis in terms of ethnicity show that Indian respondents have a high followed by the Malay respondents. In comparison, the Chinese respondents show the lowest score in identity. Respondents from the arts /social sciences also show the highest score compared to other streams.

Table 2: Identity score

\begin{tabular}{lccccc}
\hline Respondent's identity score & $\mathrm{n}(\%)$ & $\mathrm{M}$ & $\mathrm{Sp}$. & Minimum Value & Maximum Value \\
\hline Overall & $800(100)$ & 231.01 & 23.60 & 58 & 265 \\
High Score (232-265) & $437(54.6)$ & & & & \\
Low Score (53-231) & $363(45.4)$ & & & & \\
Male & $535(46.0)$ & 228.61 & 25.58 & 69 & 265 \\
Female & $183(54.0)$ & 233.05 & 21.59 & 58 & 265 \\
Malay & $535(66.8)$ & 234.47 & 20.71 & 58 & 265 \\
Chinese & $183(22.9)$ & 217.21 & 28.56 & 69 & 262 \\
Indian & $82(10.3)$ & 239.19 & 16.00 & 197 & 265 \\
Science & $317(39.6)$ & 225.54 & 26.04 & 58 & 265 \\
Arts/Social Sciences & $341(42.6)$ & 235.41 & 20.07 & 94 & 265 \\
Technical & $142(17.8)$ & 232.63 & 23.41 & 58 & 265 \\
\hline
\end{tabular}

\section{Inferential Analysis}

\subsection{Relation of age to the identity:}

Pearson correlation coefficient test performed to identify the relation of age to the identity shows that age is significantly related to the identity with results showing positive relations $(r=0.07, k=04)$.

In other words, the level of the identity improves with the increasing age of respondents. This finding is justified when considering the following opinions and studies. Gomez (1998) explains that building of the identity is an ongoing development process. Guardo and Bohan (1971) also have the opinion that the identity grows with age. Burbank (2010) in his study finds that older persons have a better identity. Thus, age is shown to be related to the level of the identity in a 
person.

Table 3: Relatioship value (r) between age and the identity of respondent

\begin{tabular}{c|cc}
\hline & Age \\
\hline identity & $\mathrm{r}=0.07$, & $\mathrm{k}=0.04$ \\
\hline
\end{tabular}

Note. ${ }^{*} k<0 . \overline{05}$

\subsection{Gender-based differences in the identity}

Independent-samples t-test performed to compare the identity scores between male and female respondents show significant differences between their scores, $\mathrm{t}(721.47)-2.63, \mathrm{k}=0.01$. Thus, the results show the identity scores for female respondents are better than for the male.This finding is in line with that in the study by Jaret and Reitzes (2009) which shows that the identity in female respondents is better than in males. In respect of Rukunegara, for example, Ramlah's (2005) study shows that the knowledge level of female students is better than that of male students.

\subsection{Differences in the identity based on place of origin}

Independent-samples t-test performed to compare scoring in the identity between respondents of urban and rural origin shows a significant difference, $\mathrm{t}_{(798)}=-3.34, \mathrm{k}=0.00$. Thus, results showed the score in the identity of rural respondents to be better than urban respondents.

Undoubtedly, certain areas are more impacted by globalization than others. Marshall (2009), for example, determined that the identity in an area of Catalonia is complex due to the impact of globalization and mass migration. Thus, individuals who reside in urban areas usually experience more globalization and progress in comparison to rural areas. Besides that, migrations from other areas to urban areas also affect identity and increase the complexity level of clarifying it. Thus, the finding of this study which shows that rural respondents have better scores in the identity than urban respondents is justified.

Table 4: Summary of t-test for the identity

\begin{tabular}{ll|ccccc}
\hline & & M & Sp. & Dk & Value t & Value k \\
\hline Gender & Male & 228.61 & 25.58 & & & \\
& Female & 233.05 & 21.59 & & & \\
\multirow{3}{*}{ Place of origin } & & & & 798 & -3.34 & 0.00 \\
& Urban & 228.49 & 23.99 & & & \\
\hline & Rural & 234.05 & 22.77 & & & \\
\hline
\end{tabular}

Note. ${ }^{*} k 0.05,{ }^{*} k<0.01$

\subsection{Differences in the identity based on field of study}

A one-way ANOVA test was performed to determine the differences in the identity among respondents based on the field of study pursued. Significant differences in the identity are shown, $F_{(2,797)}=15.35, k=0.00$. A post-hoc LSD test shows the identity in respondents of the arts/social stream is significantly different from those of the science stream while the latter also differ significantly in the identity from those of the technical stream. However, there is no significant difference between arts/social science and the technical streams.

The findings of this study show that respondents of higher institutions of learning pursuing different fields of studies differ in their levels of the identity. This gives an impression that the govenrment's strategy to foster identity among university students through compulsory civilizational courses, as noted by Mohd. Koharuddin and Zainudin (n.d) is in need of reinforcement.

Regarding this, Ramlah's (2005) study also finds differences in the identity among respondents from different fields of study. Her study on understanding, appreciation and practice of Rukunegara among students of tertiary institutes shows that arts/social science students are more exposed to matters related to Rukunegara in their study courses as compared to students of other majors. 


\subsection{Differences in identity based on ethnicity}

A one-way ANOVA test conducted to determine differences in identity based on ethnicity of respondents found significant differences, $F_{(2,797)}=46.81, k=0.00$. A post-hoc LSD test shows the identity of ethnic Malays, are significantly different from ethnic Chinese whereas the latter also differed significantly from ethnic Indians. However, the identity in ethnic Malay and Indian respondents does not show significant differences.

The findings of this study showing differences in the identity are in line with the findings of a few other studies. For example, Jaret and Reitzes (2009) found differences in the identity based on different ethnicities. Chi-Huang's study (2005) also show differences in the identity among respondents of different ethnicities. In addition, Tartakovsky (2010) also found differences in identity among respondents of different ethnicities whereby respondents from the majority ethnic group have a more positive attitude and stronger identity than respondents from the minority ethnic group.

Table 5: Summary of One-way ANOVA test for the identity variation

\begin{tabular}{|c|c|c|c|c|c|c|}
\hline Variable & & Sum of square & $\mathrm{dk}$ & Mean square & $F$ & Sig. \\
\hline \multirow{4}{*}{ Field of study } & & & & & 15.35 & 0.00 \\
\hline & Intergroups & 16502.12 & 2 & \multirow{3}{*}{$\begin{array}{c}8251.06 \\
537.63\end{array}$} & & \\
\hline & within group & 428492.82 & 797 & & & \\
\hline & Total & 444994.94 & 799 & & & \\
\hline \multirow{4}{*}{ Ethnicity } & & & & & 46.81 & 0.00 \\
\hline & Intergroups & 46778.54 & 2 & \multirow{3}{*}{$\begin{array}{c}23389.27 \\
499.64\end{array}$} & & \\
\hline & Within group & 398216.40 & 797 & & & \\
\hline & Total & 444994.94 & 799 & & & \\
\hline
\end{tabular}

\section{Consclusion}

In conclusion, the identity of this sample is going to reach alarming levels. In terms of language, there are many respondents who would rather prefer their mother tongue as the language of everyday use, and not all respondents who are Malaysian citizens have mastered the national language. The identity indicated by the respondents of this study is the ethnic identity rather than the national identity. The lesson learnt from earlier studies also show that there are threats to individual identity such as the factors of globalization, migration and political changes which must also be taken into consideration. Therefore, continuous efforts should be made to strengthen and reinforce the national identity of the nation's population. In Malaysia, building national identity is an ongoing process. Hence, various programs and activities can be planned for the Malaysian population. More detailed planning can be developed for the youth who will be the future leaders.

Based on the findings of this study, among the matters which need to be given attention in order to strengthen national identity among Malaysians is that the national identity emphasized upon must contain the element of a sense of belonging to the nation-state. In other words, the people who have an identity must love the nation- state. In addition, national identity stressed on by the state must take into account the ethnic and cultural diversity which makes the state unique. The expected output is an individual and society with a high identity while still practising their respective cultures and customs. Further, the said identity should not lead to ethnic disintegration. This means that individuals from any ethnic group are free to practise their respective cultures and customs while sharing the same national identity with other individuals from other ethnic groups as Malaysians. As Malaysia is a multiethnic nation, the probable tendency for ethnic assimilation exists. Hence, the struggle to shape a national identity should not cause a loss of identity as an ethnic group.

\section{Acknowledgement}

This study is financed by the research project on Identity of Higher Learning Student's in Malaysia, ID: UKM-GPP-PPKK5-2009, and the project on Pengukuhan Akal Budi Belia Melayu Islam, ID: TD-2014-007 which is funded by The National University of Malaysia.Special acknowledgement to researchers for this research project.

\section{References}

Ab. Rahman, M. \& Amidin, Z. n.d. Practicing of good conduct among students: a study in Terengganu. Retrieved from http://search. proquest.com/docview/219177181?pq-origsite=gscholar. 
Burbank, H. 2010. German national identity: patriotism and stigma. Stanford Undergraduate Research Journal, 9.

Chi-Huang. 2005. Dimension of Taiwanese/Chinese identity and national identity in Taiwan: a latent class analysis. Journal of Asian and African Studies, 40: 51-70.

Collet. B. A. 2007. Islam, national identity and public secondary education: perspectives from the Somali diaspora in Toronto. Race, Ethnicity and education, 10(2): 131-153.

Desai, C. M. 2006. National identity in a multicultural society: Malaysian children's literature in English. Children Literature in Education, 37(2): 163-184.

Dictionary of Dewan. 2007. Kuala Lumpur: Dewan Bahasa dan Pustaka.

Dingley, J. 2009. Religion, truth, national identity and social meaning: the example of Northern Ireland. National Identities, 11(4): 367383.

Ennaji, M. 2005. Multilingualism, cultural identity and education in Morocco. New York: Springer.

Fariza Md Sham. 2013. Personality from al-Ghazali Perspective. Bangi: UKM Press.

Al-Ghazali. 2000.Ihya'Ulum al-Din. Kaherah: Dar al-Taqwa li al-Turath

Gomez, A. V. 1998. The construction of national identity as a development process from childhood to adolescence in Catalonia. Doctoral Dessertation, Department of Psychology, Unversitat de Girona.

Guardo, C. J. \& Bohan, J. B. 1971. Development of self-identity in children. Child Development, 42(6): 1909-1921.

Ismail Bakar. 2010. Sejarah kepimpinan dan politik ke arah pembentukan jati diri kebangsaan (History of leadership and politic towards developing national identity). In Mohd Yusof Othman (Ed.) National identity 'manhaj Islam Hadhari'. Bangi: Institute of Islam Hadhari, National University of Malaysia. Pp. 197-210.

Ismail Ibrahim. 2010a. Gagasan 1Malaysia, Peradaban dan Identiti Bangsa: Pendekatan Hadhari (Idea of 1Malaysia, civilization and national identity: 'hadhari' approach). Bangi: Institute of Islam Hadhari UKM, Malaysia.

Ismail Ibrahim. 2010b. 1Malaysia: pembentukan jati diri kebangsaan (Developing national identity). In Mohd Yusof Othman (Ed.) National identity 'manhaj Islam Hadhari'. Bangi: Institute of Islam Hadhari, National University of Malaysia.. Pp. 3-20.

Jaret, C. \& Reitzes, D. C. 2009. Currents in a stream: college student identities and ethnic identities and their relationship with selfesteem, efficacy, and grade point average in an urban university. Social Science Quarterly, 90(2): 346-367.

Kurth, J. 2007. Religion and national identity in America and Europe. Society, 44(6): 120-125.

Lee Yok Fee. 2009. Research on Chinese identity in Malaysia from epistemology: a comment. Sari, 27: 167-183.

Marshall, S. 2009. Language and national identities in contact: the case of Latinos in Barcelona. International Journal of Iberian Studies, 22(2): 87-107.

Matera, C., Giannini, M., Blanco, A. \& Smith, P. B. 2005. Autostereotyping and national identity in the Spanish context. Interamerican Journal of Psychology, 39 (1): 83-92.

Mendelsohn, M. 2002. Measuring national identity and patterns of attachment: Quebec and nationalist mobilization. Nationalism and Ethnic Politics, 8(3): 72-94.

Miedema, S. 2009. Educating for religious citizenship: religious education as identity formation. DIm. M. de Souza et al. (Pnyt.). International handbook of the Religious, Moral and Spiritual Komponenons in Education, hlm. 967-976.

Misran, R. 2006. National ideology in Malaysian Children's novels: an analysis of the novel Anak Din Biola. Jurnal e-Bangi, 1(1).

Mohd. Koharuddin M. B. \& Zainudin, H. n.d. Pendidikan ketamadunan dan cabaran pembinaan bangsa Malaysia (Educational civilization and challenges of developing Malaysian nationality). Retrieved from eprints.utm.my/2340/1/koharuddin.doc. 20 Oktober 2010.

Nor Hashimah, J, Junaini K., Zaharani A. 2010. Socio-cognitive among adolescence students towards Malay language. GEMA Online Journal of Language Studies 10(3): 67-87.

Ramlah Adam. 2005. Research on level of understanding, appreciation and practicing 'Rukunegara' among students in higher learning institution. Unpublished research report. Department of Unity and National Integrity Research Grant.

Samsudin A. Rahim. 2001. "Media and Culture Identity: Community Media Challenge Malaysia Century 21". Working paper presented at the National Symposium on Social Issues and Challenges Malaysia, University of Malaya, Kuala Lumpur.

Tan Bee Chu. 2010. Penghayatan Rukunnegara dalam latihan keguruan (Appreciating 'Rukunegara' in teaching training). Unpublished paper. Raja Melewar Teachers Training Institute, Negeri Sembilan, Malaysia

Tan Chee-Beng. 2000. Ethnic identities and national identities: some examples from Malaysia. Identities, 6(4): $441-480$.

Tartakovsky, E. 2009. National identity of high-school adolescents in an era of socio-economic change: Russia and Ukraine in the PostPerestroika period. Journal of Youth and Adolescence, 39. DOI: 10.1007/s10964-010-9509-6.

Theriault, B. \& Peter, F. 2005. Introduction: Islam and the dynamics of European national Identities. Journal of Contemporary European Studies, 13(3): 261-266.

Utusan Malaysia. 2010. Orang muda buta sejarah (Young people history blind) 28 Oktober, p.3

Wan Muhamad, S. A. A. 2010. Strategi, kaedah dan pelaksanaan dakwah dalam membina jati diri kebangsaan (Strategy, method and implementation of da'wah in developing national identity). In Mohd Yusof Othman (Ed.) National identity 'manhaj Islam Hadhari'. Bangi: Institute of Islam Hadhari, National University of Malaysia. Pp. 85-96.

Zainul Rijal, A. B. 2010. Undang-undang Islam di Malaysia: ke arah pembentukan jati diri kebangsaan (Islamic law in Malaysia: towards development of national identity). In Mohd Yusof Othman (Ed.) National identity 'manhaj Islam Hadhari'. Bangi: Institute of Islam Hadhari, National University of Malaysia. Pp. 67-84.

Zambeta, E. (2010). Religion and national identity in Greek education. Intercultural Education, 11(2): 145-155. Retrieved from http://search.proquest.com/docview/219177181?pq-origsite=gscholar 